\title{
EAl Endorsed Transactions

\section{Determining the Degree of Increasing Locomotive Diesel Economic Efficiency by Modernization of the Speed Controller}

\author{
A. Bogajevskiy ${ }^{1}$, Shch. Arhun ${ }^{1, *}$, V. Dvadnenko ${ }^{1}$ and S. Ponikarovska ${ }^{1}$ \\ ${ }^{1}$ Kharkiv National Automobile and Highway University (KhNAHU), 25, Yaroslav Mudryi street, Kharkiv, Ukraine 61002
}

\begin{abstract}
The powerful means of improving the economy of locomotives during modernization is introduction of electric speed and power controllers, including the ability to control the moment of the fuel supply start. In the depot of the South Railway (Kharkiv, Ukraine), the electronic controller for the speed and power of the diesel generator and standard hydraulic speed and power controller were compared by operational tests at two sections of the freight mainline locomotive of 2 TE116 type. The tests were being carried out under real operating conditions during 1-year period. The results showed reduction in fuel consumption in operation up to $6 \%$ on a diesel generator equipped with an electronic controller. The rate of the increased operational fuel economy can be given in technical materials only in relative units. The obtained results can be used in substantiating the application of various technical control and management systems.
\end{abstract}

Keywords: diesel-generator unit, locomotive, diesel locomotive, speed controller, fuel economy.

Received on 02 January 2020, accepted on 16 January 2020, published on 30 January 2020

Copyright (C) 2020 A. Bogajevskiy et al., licensed to EAI. This is an open access article distributed under the terms of the Creative Commons Attribution licence (http://creativecommons.org/licenses/by/3.0/), which permits unlimited use, distribution and reproduction in any medium so long as the original work is properly cited.

doi: 10.4108/eai.13-7-2018.162827

"Corresponding author. Email: shasyana@gmail.com

\section{Introduction}

To date, the problems of ecology and resource-saving strongly require using energy-saving technologies. This situation has directly affected the transport industry. In most developed countries, the replacement of vehicles with ICE by electric analogs is advocated [1-6] or hybrid vehicles $[7,8]$. But such a transition cannot be instantaneous for both technical and economic reasons. It is especially true for the transport using powerful dieselgenerator sets (DGS).

At present, thousands of railway and industrial vehicles for various purposes are equipped with medium-speed diesel generators having the capacity of $600 \mathrm{~kW}$ and more. Each powerful DGS, on condition of continuous operation, consumes several hundred tons of fuel per year; i. e. the entire park consumes millions of tons of fuel annually. Therefore, improving the efficiency of rail transport [9], in particular diesel locomotives, through its modernization is an important task [10].

Modernization of locomotives is aimed at:

- increasing fuel economy;

- increasing mileage between repairs;

- improving the working conditions of the driver;

- improving ecological indexes.

Modernization of diesel locomotives includes modernization of the diesel-generator set in the first place. It is a well-known fact, that high requirements for safety, reliability and lifetime are put forward to diesel locomotive generators. The cost of a DGS of 1.0 MW capacity or more starts from hundreds of thousands of dollars. The term of their operation, is, as a rule, dozens of years. Therefore, any improvements in the DGS are accepted for production only after thorough, comprehensive and long-term testing in conditions of severe operation. 
Studying the experience of Lithuania, Latvia, Poland, Hungary, Slovakia, and Germany has shown that these countries prefer modernization of the existing diesel locomotives to their replacement [10-13].

For example, the authors of [14] proposed to replace special electric machines for excitation of traction generators for non-contact semiconductor static converters and to use control systems for locomotive parameters based on a microprocessor. This allowed improving the working conditions of a driver and increasing traffic safety. According to the authors of this article, this modernization has helped to reduce fuel consumption of diesel locomotives such as TEP-70M to $20 \%$, and fuel consumption of locomotives to $25 \%$ [14]. But the modes of operation and the speeds, at which such a fuel economy was observed, are not specified. Therefore, the statement about the effectiveness of this modernization is not fully substantiated.

One way to improve locomotives is to use an unconventional traction drive, for example, a hybrid traction drive $[15,16]$. The hybrid drive includes an internal combustion engine and an energy storage device. The parameters of such a traction drive should be based on the analysis of real operating modes of locomotives.

Modern diesel generators operate in a wide range of speed and load modes and constitute a combined unit comprising several heterogeneous subsystems that interact with each other during operation. The most important are the subsystems of fuel supply, air supply and cooling. When creating such a combined installation, individual characteristics of the subsystems can be coordinated only in one single mode, most often at the nominal mode. If the operating mode is different from the nominal one, then the consistency of the subsystems is violated, which causes deterioration of the quality of the diesel's working process and decrease of its economic and environmental characteristics. Ensuring precise effective tuning of the characteristics of diesel subsystems in the course of operation at different modes and with changing operating conditions is possible with the use of modern automatic control systems. The simplest and most effective means of influencing the working process of a diesel engine is controlling the fuel supply process. The amount of the supplied fuel is determined by such factors as:

- the design of the power plant;

- the speed and load modes under operating conditions;

- adjustment of various restrictions.

- One of the ways to improve the performance of transport diesels is to improve the fuel supply control process. It includes:

- raising the injection pressure to increase the fineness of spraying the fuel and ensure the optimal injection time;

- optimizing the injection characteristic (fuel supply law), i.e. ensuring a smooth start of injection and a sharp end to reduce noise;
- ensuring the optimal fuel supply and the start time of injection at the start-up modes and adjusting the start of injection in the load and speed functions;

- correcting the fuel supply process depending on the changes in external conditions and operating mode;

- increasing the accuracy of fuel dosing;

- maintaining stability of parameters of fuel delivery in operating conditions;

- providing forced transfer of the diesel engine to the zone of the best economy in steady modes.

Modern means of controls make possible to improve the operational characteristics of diesel locomotive power plants, eliminating smoke and increasing reliability at low costs.

For example, in article [10] the Polish scientists presented the concept of modernization of the load control system of the diesel locomotive drive unit using the example of the series SM31 locomotive. The proposed solution uses the electronic speed and power controller of the a8C22W diesel engine. A new optimal performance characteristic is being realized at this.

One of the most effective areas for improving locomotive diesels is modernization of the crankshaft speed controllers. This allows reducing the operational fuel consumption $[17,18]$. With this modernization, it is necessary to take into account the specifics of the working processes in engines [19]. There are several methods of this modernization. They differ not only technically, but also by the degree of their operational efficiency and material costs.

Therefore, the purpose of this paper is to determine the degree of increase in locomotive diesels economic efficiency.

To achieve this goal it is necessary:

- to analyze the main directions of modernization of the locomotive crankshaft speed controllers;

- to substantiate the most suitable directions of modernization in order to achieve the greatest fuel efficiency of the locomotive in operation;

- to conduct a theoretical assessment of possible fuel economy of the locomotive diesel-generator set;

- to conduct a practical assessment of diesel fuel economy by conducting diesel locomotive tests in real operating conditions

The comparative tests were carried out in the railway depot Osnova of the South Railway of Kharkiv (Ukraine) on a two-section freight mainline diesel locomotive of 2TE116 type. One section was equipped with a hydromechanical controller, the second - with an electric controller. The test period was 1 year. 


\section{Options of modernization of crankshaft speed controllers}

The classical hydromechanical controller installed on locomotive diesels generators includes: a mechanism to control setting the rotational speed of the crankshaft (unit of tightening the all-mode spring); a proportional-integraldifferential (PID) controller - a hydraulic controller with a crankshaft speed meter; a mechanism for driving the rack of a high-pressure mechanical fuel pump.

There are three main areas of modernization:

- modernization 1 - partial modernization of the existing controller;

- modernization 2 - a complete replacement of a hydromechanical controller with an electric regulator with a microcontroller control;

- modernization 3 - a complete replacement of the hydromechanical controller with an electric controller with a microcontroller control and the ability to control the moment of the fuel supply start (a non-cordless fuel system with microcontroller control of fuel supply to each cylinder).

Each of these options has its advantages and disadvantages. Therefore, the choice depends on a number of factors: the material costs of modernization, the expected result in subsequent operation and the performance potential.

\subsection{Modernization 1}

It is a partial modernization, which basically involves replacement of the speed setting mechanism. The best known are two types of design for the speed setting control mechanism:

- the mechanism with direct action on the all-mode spring with the help of 4 power solenoids, which create a compression force of the all-mode spring through the general lever. The change in the compression force of the spring occurs in a jumplike manner and depends on the combination of switching on the Electromagnet;

- the mechanism which acts on the all-mode spring through the gearbox, which is driven by an electric motor. The mechanism contains a contact feedback sensor of the rotary type, which determines the number of frequency speed setting positions and the spring compression force corresponding to each position. The change in the compression force of the spring is smooth. The speed of movement from one speed setting to the other is determined by the speed of rotation of the reducer shaft and is constant. The group of contacts of the feedback sensor corresponding to the determined tightening torque of the all-mode spring, are geometrically arranged strictly along the circumference through a certain angle which cannot be changed.

The given modernization is the cheapest, but it is less effective than those discussed below. Therefore, in this work, there is no point in considering it in more detail.

Features and possibilities of partial modernization to improve the economy of locomotive diesel should be considered in a separate publication.

\subsection{Modernization 2}

Modernization 2 suggests complete replacement of a hydromechanical controller by an electric controller with a microcontroller control.

The block diagram of a typical electric controller, which is most often used in modernization of locomotive diesel generators, is shown in Figure 1.

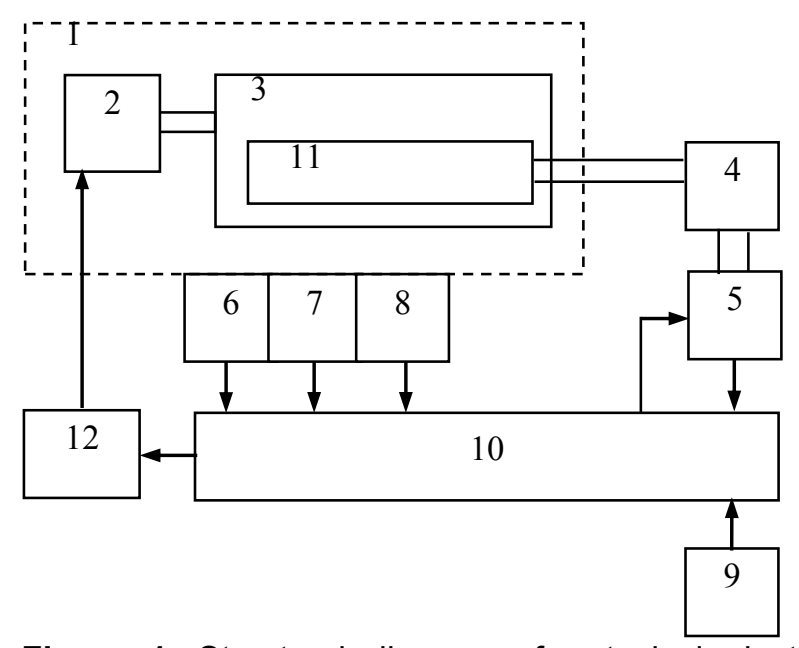

Figure 1. Structural diagram of a typical electric controller: (1) DGS; (2) generator; (3) diesel engine; (4) actuator; (5) sensor for moving the racks of mechanical high-pressure fuel pumps (HPFP); (6) sensor of a crankshaft speed; (7) sensor of temperature of a cooling liquid in diesel engine; (8) sensor of pressure of air pressurization; (9) device for specifying diesel shaft speed; (10) microcontroller control unit; (11) HPFP; (12) generator load power control unit.

The executive mechanism 4 (Figure 1) can be implemented in two ways:

- with the use of a powerful electric actuator with a large torque. This actuator acts directly on the fuel pump racks, regulating fuel supply. In world practice, the most powerful actuators of German and American manufacturers are most often used [20, 21]; 
- using an electrohydraulic device that contains an actuator of various manufacturers of low power with a small torque. This actuator acts on a linear hydraulic amplifier. This amplifier acts on the fuel pump rods. In modernization practice, similar electrohydraulic devices are also widely known [22, 23].

Each of the ways of implementing actuator 4 has its advantages and disadvantages.

An obvious advantage of the considered ways of implementing actuator 4 with different actuators is the presence of a built-in displacement sensor 5, which is used as a feedback sensor for the load of the diesel generator. This is exactly what makes it possible to implement in the controller the possibility of forced transfer of the diesel generator to the zone of the best economy in the process of operation and, thus, to improve economic performance of the vehicle during operation. In addition, in such an embodiment of the powerful diesel controller, it is possible to harmonize the fuel and air supply subsystems in the diesel engine, as well as various limiting and protective functions. In this case, microcontroller is always the control system.

The disadvantage of modernization 2 is the lack of control over the timing of fuel injection depending on the speed and load of the diesel generator, except when this possibility was provided for in the diesel engine design.

\subsection{Modernization 3}

Modernization 3 is a complete replacement of the hydromechanical controller with an electric controller with a microcontroller control and the ability to control the moment of the fuel supply start (a non-accumulator fuel system with microcontroller control of the fuel supply to each cylinder)).

The block diagram of the electric controller with the possibility to control the moment of the fuel supply start is shown in Figure 2.

The signals from sensors 5-9 and mechanism 11 are fed to the corresponding inputs of the microprocessor control unit (MCU) 10, which processes them and gives signals to the outputs connected to the input of actuator 4 for moving HPFP injection rack 14 and the inputs of the control solenoid valves $(\mathrm{SV}) 13.1 \div 13 . \mathrm{n}$ ( $\mathrm{n}$ is the number of cylinders of diesel engine 3 ), which are integrated in injection pump 14, thus regulating the fuel supply to diesel engine 3 .

The signals from the sensors and the speed reference mechanism are processed in MCU 10, where the signs of traffic conditions are determined, the information about which is fed to the output of MCU 10, which is connected to the input of the load power control unit 12, the output of unit 12 is connected to the input of generator 2 of the DGS TC 1.

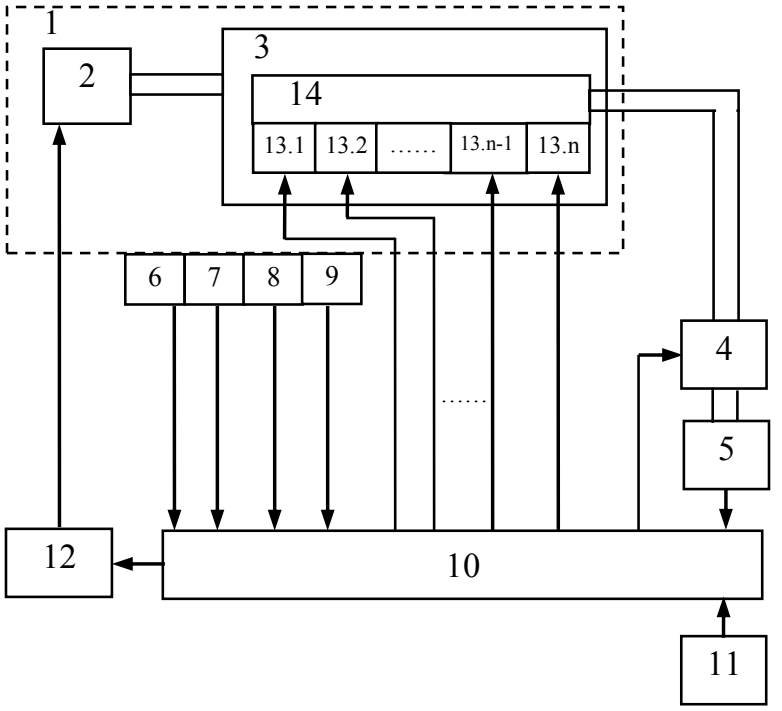

Figure 2. Structural diagram of the electric controller with the possibility to control the moment of the fuel supply start: (1) DGS; (2) generator; (3) diesel engine; (4) actuator; (5) sensor for moving the racks of mechanical HPFP; (6) sensor of a crankshaft speed; (7) diesel temperature sensor; (8) sensor of pressure of air pressurization; (9) TDC

(10) microcontroller control unit; (11) device for setting the diesel engine shaft speed; (12) generator

load power control unit; (13) regulating solenoid valves (SV) $13.1 \div 13 . n$ ( $n-$ number of cylinders of the diesel engine 3); (14) HPFP

The control system works as follows. The parameter that determines the load power of diesel engine 3 and, accordingly, of diesel generator set 1 , is the amount of fuel that enters diesel engine 3 through HPFP 14 equipped with $13.1 \div 13 . n$ regulating $\mathrm{SV}$ and the control rack of mechanism 4. The amount of fuel depends both on the duration of the time when the SV control valves are turned on and the moment when the SV is turned on (i.e. the moment of the fuel supply start) in the load and speed function. The moment of activation of the corresponding $\mathrm{SV}$ is determined based on the signal from the top dead center (TDC) sensor 9, and the maximum regulation range of the ON state of the SV is limited by the forward travel time of the camshaft drive cam of HPFP 14. To provide the maximum control range for both the on-time status of the SV, SV start moment, actuator 4 during the operation of the DGS TC 1 keeps the HPFP racks 14 in the maximum feed position, which is controlled by sensor 5 . SV regulating valves are controlled by the MCU 10 based on the available in memory (optimal or empirical) corresponding load power control algorithms and speed control algorithms and the moment of the fuel supply start in the function of load and speed. When the diesel is in operation, the plungers of the high-pressure fuel pumps are constantly in the maximum feed position. 
The obtained control characteristics ensure minimum deviations of the load powers from the optimal values with more economical fuel consumption.

The option of modernization 3 (Figure 2) uses design solutions that are known under the designations UPS (united pump system) or PPN (pump-pine-noozle) [11] and implemented in [14]. This design solution, due to the presence of the actuator combines both directions 2 and 3 of the complete modernization: both the fully electric controller and the non-accumulator system with the control of the fuel supply starting moment. In this case, the main option is a non-accumulator system with the control of the moment of the fuel supply start. If this system fails, the control valves are turned off and the system is transformed into a fully electric controller in which the actuator acts on the fuel pump racks. In this case, the diesel engine of the vehicle is operable until the main system is operational. Thus, the idle time of the vehicle is reduced.

It should be noted that the most progressive at this time is the injection system with a Common rail type fuel accumulator. The given fuel system provides regulation of fuel injection advance angle and considerable decrease in fuel consumption. At the same time, it has a significant drawback in the form of an additional complex highpressure fuel system. It is technically very difficult to implement the installation of such a system on an ordinary powerful transport diesel for the purpose of its modernization. In order to avoid the risk of using a system with a fuel accumulator due to high pressure and unsafe practical applications, the main focus of operating organizations in different countries was aimed at implementing the three above-mentioned areas of modernization. The cost of modernization depends on the choice of direction: direction 1 requires the lowest costs, direction 3 is the most expensive.

\section{Theoretical and practical evaluation of fuel economy of DGS}

The real performance indicators of fuel economy for powerful diesel generators with an advanced fuel control system are of interest. In their technical materials manufacturers of equipment $[6,7]$ do not provide information about the expected fuel economy in vehicle operation, since they do not directly operate the rolling stock. At the same time, it should be noted that not only the potential of modernized fuel control systems can help reduce operating costs.

Total fuel consumption in the operation of the locomotive diesel generator can be represented by the following expression:

$$
B_{\Sigma}=B_{t}+B_{i m}+B_{e s}
$$

where $B_{t}$ - fuel consumption for traction modes, $B_{i m}-$ fuel consumption in idling mode, $B_{\mathrm{es}}-$ fuel consumption for engine start.

The components of expression (1) can be presented as follows:

$$
\begin{aligned}
& B_{t}=g_{t} \cdot t_{t} \\
& B_{i m}=g_{i m} \cdot t_{i m} \\
& B_{e s}=g_{e s} \cdot n
\end{aligned}
$$

where $g_{t}, g_{i m}-$ average fuel consumption per time unit for traction mode and idling mode correspondingly, $g_{e s}-$ average fuel consumption for diesel start mode, $t_{t}, t_{i m}-$ time of operation on traction mode and idling mode correspondingly, $n$ - number of diesel starts of a shunting diesel locomotive per shift.

From the analysis of expression (2) it follows that modern fuel control means do not have any effect on some of the parameters, for example, $t_{i m}$ and $n$.

A significant number of DGS locomotives of industrial enterprises and railways of different countries and companies are not equipped with modern electronic fuel control facilities. Therefore, the main direction of reducing fuel consumption during operation is aimed at reducing the indicator $t_{i m}$ to the technologically necessary value. The value of $t_{i m}$ is the most important parameter for locomotive systems of the "start-stop" type. This value is also dependent on a number of parameters of the locomotive, such as: the state of the battery, the temperature, the pressure in the braking system, etc. Parameter $B_{e s}$ is connected with $t_{i m}$, the decrease of $t_{i m}$, naturally, causes an increase of the number of starts $n$, thus, an increase in the component of the $B_{e s}$ in the formula (1).

The issue of determining $B_{e s}$, its share in total fuel consumption and the possibility of influencing its reduction by means of electric controllers requires a separate study. Although most likely the share of these costs in total expenditure is negligible. Investigation of the $B_{e s}$ component is of interest in terms of the ongoing charge-discharge processes in the starter battery. Therefore, it is necessary to analyze the effect of electrical controllers on the decrease in parameters $g_{t}$ and $g_{i m}$, which are part of $B_{t}$ and $B_{i m}$ in formulas (1) and (2) and, consequently, their effect on reducing total fuel consumption.

An effective means of reducing fuel costs at idle is the use of electric controllers to reduce the minimum idling speeds. To confirm this statement, the authors of the work have carried out the research [24]. They moved on a locomotive diesel generator with an electric controller without the possibility of regulating the moment of fuel supply start. Experimentally, it was found that reduction in the minimum idle speed by $1 \%$ leads to a reduction in fuel consumption at the same frequency by about $1 \%$. In operation with a diesel locomotive of the 2 TE10 type, when the minimum idling frequency was reduced from 
$400 \mathrm{rpm}$ to $270 \mathrm{rpm}(32.5 \%)$, fuel economy at the minimum idle speed ratio was approximately $27 \%$.

Thus, it can be stated that a reduction in the idling frequency is a source of increased economy. At the same time, it is necessary to take into account a number of features that affect the operation of both the diesel engine and the vehicle as a whole with a decrease in the minimum idling frequency:

- when the idling speed is reduced, the speed of the camshaft driving the high pressure pumps is reduced. Consequently, the rate of pressure build-up in nozzle atomizers is reduced, the conditions for atomizing the fuel in the combustion chamber and the burning process of the fuel are deteriorating. There may also be misfiring of some fuel portions;

- the pressure in the engine lubrication system is reduced, which can negatively affect the reliability of the diesel engine piston system;

- the charging system of the locomotive battery may deteriorate;

- if the locomotive has the elements of hydraulic transmission, a significant decrease in the idle speed may cause the impossibility of the hydraulic system functioning.

Therefore, lowering the minimum frequency of idling with the aim of increasing the economy of the diesel should be handled with these limitations in mind, although the fuel economy figures look impressive (at least $10 \%$ ).

It should be noted that the misfiring of some portions of the fuel at idle can be eliminated using spraying nozzles with an integrated accumulator. Their use also increases the economy of the locomotive diesel engine at idling speed by about the same 10\% with significantly lower modernization costs compared to the use of electric controllers.

Electric controllers are able to demonstrate more significant indicators of increasing economy at idle speed with the possibility of regulating the timing of the fuel supply start (modernization 3). The reason for this is two additional factors: firstly, the maximum fuel volume is always supplied to the high-pressure pump, therefore, there are always conditions for high-quality injection ahead of the nozzle atomizer, and thus, there are practically no conditions for skipping the injection and combustion of some fuel portions at idle speed; secondly, due to the ability to regulate the fuel supply start, combustion takes place at the moment (relative to the TDC), the most favorable in terms of the working process in the diesel cylinders.

It is important that the specific fuel consumption at idling is many times less than the specific fuel consumption when operating under load (work in traction mode). Therefore, it is only possible to roughly quantify the effect of even relatively significant reduction of fuel consumption at idle on the total costs in expression (1) in actual operation. For example, for this purpose a computer model similar to the model in [25] can be used, and as an object of investigation of operational work, a conditional production cycle, with certain duration in time (about 11 minutes) can be chosen by calculation [17].

When studying fuel consumption for traction work, it should be mentioned that in expression (2) influencing the decrease in the time for executing traction (useful) work $t_{t}$ is impossible. Therefore, the factors affecting reduction of the total fuel consumption due to the decrease in the $g_{t}$ must be analyzed.

There are some possibilities to reduce $g_{t}$ by means of electric controllers. For example, ensuring the forced transfer of a diesel engine to the zone of the best economy in steady states; control of transient processes to ensure effective coordination of the fuel supply and diesel air supply subsystems in the process of changing the speed and load modes during operation.

We must not forget about the possibility of regulating the timing of the fuel supply start, especially at speeds close to the minimum idling frequency (modernization 3 ). The effect of this factor begins to decrease significantly as the speed of rotation increases and practically disappears when the frequency approaches the nominal value. This is due to the design of the diesel engine.

Theoretical studies, in particular [26], have shown that when using the above approaches to reducing the $g_{t}$ value for steady and transient modes, the economy of a locomotive diesel generator can increase by $4-5 \%$. During the studies, the possibility of applying an electric controller without the possibility of controlling the moment of fuel supply was considered.

Proceeding from all the above, theoretically it is only possible to predict the degree of influence of various technological possibilities of electric controllers on reducing the operational consumption of a vehicle with a powerful DGS. Various kinds of experimental tests of the DGS in separate modes are able to show only the potential of the electric control system for a particular frequency and load mode. However, it cannot be asserted that the results of reducing fuel consumption during the actual operation will eventually be the same as for the bench tests in any one mode. It follows from expressions (1) and (2) that real operational work is a combination of idling and load-handling modes and their ratio for each particular work performed is different. Moreover, such time parameters in expression (2) as $t_{i m}$ and $t_{t}$ to a certain extent depend on the level of professionalism of the operator - the driver.

The only approach to determining the true magnitude of the effect of electric controls on reducing fuel consumption in actual operation is comparative testing.

\section{Testing electronic controller of locomotive diesel controllers}

In accordance with the "Operational test program for the electronic controller of locomotive diesel generators" in the depot Osnova of the South Railway (Kharkiv, 
Ukraine), a DGS electric controller of the engine speed and power was installed in section " $\mathrm{A}$ " of the freight twosection mainline diesel locomotive of 2ТЭ116 №1084 type, Figures 3, 4. The diesel generator of section "B" was equipped with a standard hydraulic controller. The DGS of the locomotive has a diesel engine of 5D49 type with 16 cylinders and a nominal traction power of up to $2000 \mathrm{~kW}$.

The controller was developed and manufactured in Ukraine in cooperation with company "Heinzmann" (Germany).

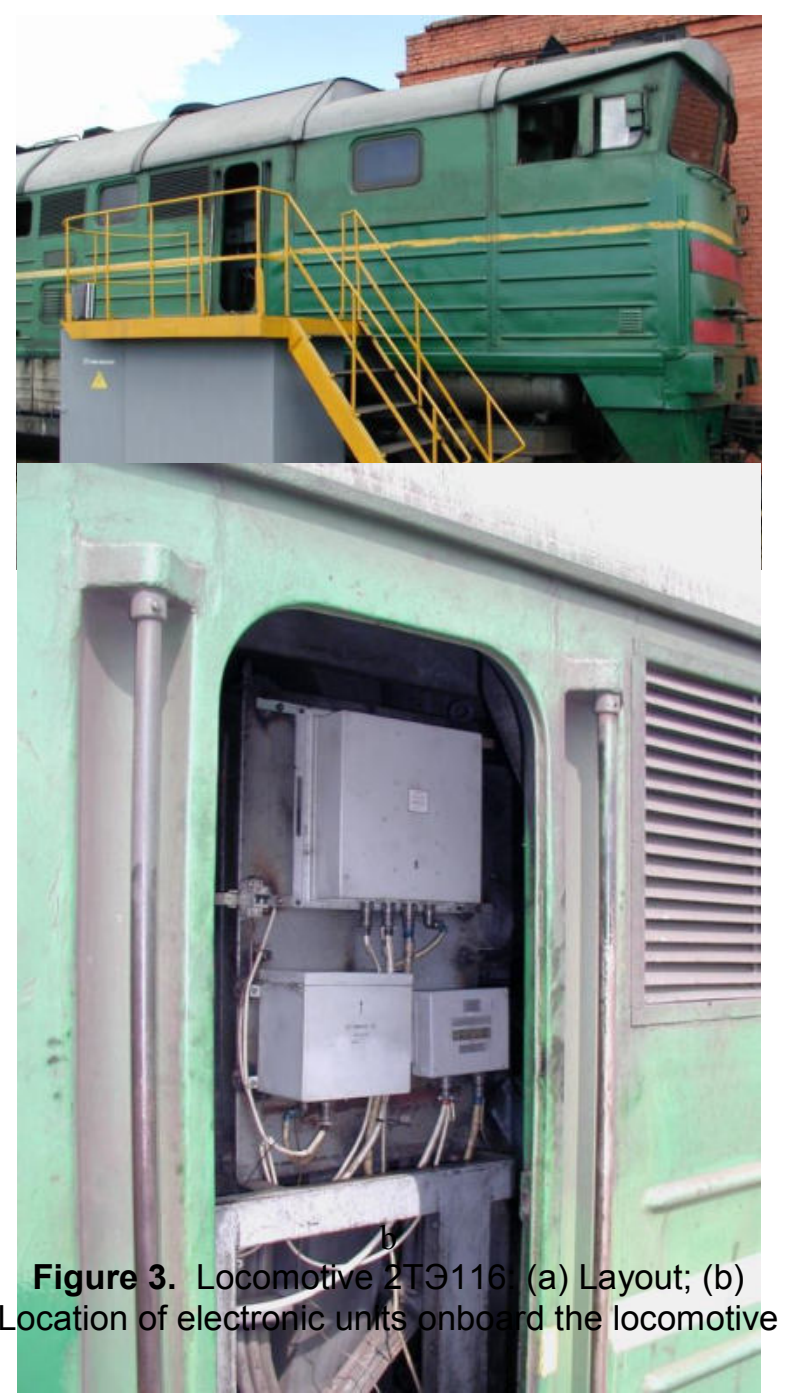

The conditions for conducting comparative tests of the two types of controllers are identical, because both controllers were on the same locomotive in different sections, they worked simultaneously and were controlled by the same driver-operator. Both sections of the locomotive had the same technical condition, the same settings for the speed and load parameters. Both sections performed the same production task simultaneously. The sections of 2TE116 diesel locomotive were equipped with controllers without the possibility of regulating the moment of fuel supply start.
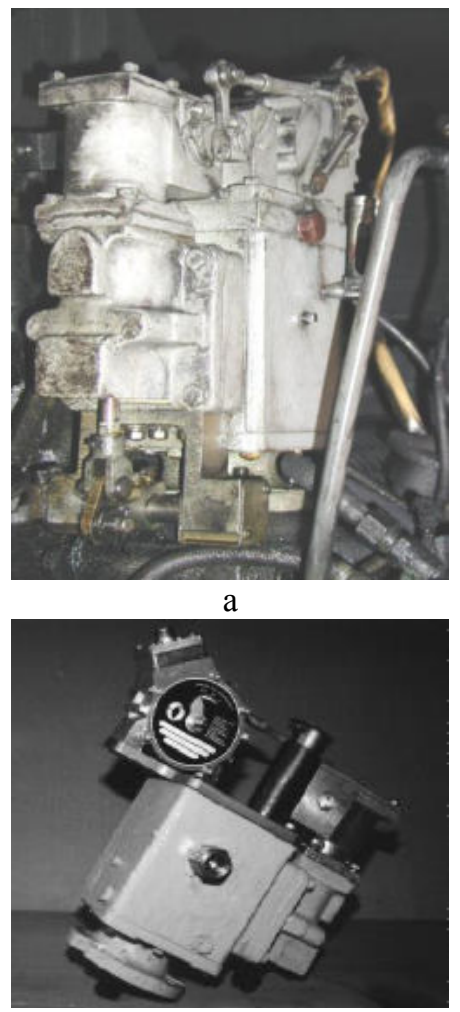

b

Figure 4. Actuator: (a) Mounting on 2TE116 locomotive diesel; (b) Layout

Comparative tests lasted for about 1 year. The fuel consumption indicators for each locomotive section were recorded at certain intervals.

\section{Results and discussions}

The test results can be presented in several paragraphs.

1 During the period of the research the No. 1084 diesel locomotive's run comprised $52.726 \mathrm{~km}$ (accounts by the Osnova depot).

2 No failures in the operation of the electronic controller are fixed.

3 To obtain a comparative estimation of the operational fuel consumption of sections " $A$ " and " $B$ " in the Osnova depot, some works were carried out to adjust the same power levels in two sections. The power indicators for the sections are received, Table 1.

Table 1 - Adjustment of power indicators by sections "A"

\begin{tabular}{l|c|c|c|c}
\multicolumn{4}{c}{ and "B" } \\
\hline $\begin{array}{l}\text { № locomotive } \\
\text { controller position }\end{array}$ & 6 & 9 & 13 & 15 \\
$\begin{array}{l}\text { Section “A" with } \\
\text { electronic speed } \\
\text { controller, kW }\end{array}$ & 618 & 1015 & 1628 & 1900 \\
$\begin{array}{l}\text { Section "B" with } \\
\text { hydraulic speed } \\
\text { controller, kW }\end{array}$ & 619 & 1050 & 1606 & 1920 \\
\hline
\end{tabular}


On section " $A$ " optimization of the transient modes of DGS operation was carried out. The setting of the DGS of section "A" with the help of an electronic controller for the most economical operation modes by the positions of the driver's controller was not performed.

4 The locomotive was operated on various sections of the Southern Railway in normal conditions.

5 The fuel consumption for the first control period of time by sections at a run of $10044.0 \mathrm{~km}$ was (accounts by Osnova depot):

- section "A" - $34416 \mathrm{~kg}$;

- section "B" - $36301 \mathrm{~kg}$.

The fuel consumption of section " $A$ " of a diesel locomotive equipped with an electronic controller is 1885 $\mathrm{kg}$ less than the consumption of section " $\mathrm{B}$ " with a common controller, which amounts to $5 \%$ of savings.

6 . The fuel consumption for the 2 nd control period of time by sections with a run of $7026.0 \mathrm{~km}$ was (accounts by Osnova depot):

- section "A" - $25550 \mathrm{~kg}$;

- section "B" - $27197 \mathrm{~kg}$.

- The fuel consumption of section " $\mathrm{A}$ " is $1647 \mathrm{~kg}$ less than the consumption of section "B", which is $6 \%$ of savings.

Conclusions and recommendations on the results of comparative tests. The use of an electronic controller without the possibility of regulating the timing of the fuel supply start in the DGS on the basis of 5D49 diesel improves the fuel efficiency by $5-6 \%$.

Analysis of loading and speed modes of powerful transport diesel engines allows making an assumption that regulation of the moment of the fuel supply start will cause reduction of fuel consumption by another $2-4 \%$. The total decrease in the average operating fuel consumption may amount to $7-10 \%$. The result depends on the time during which the locomotive diesel generator will operate at modes close to the minimum idling frequency. It is in this range that the effect of this parameter on the best course of working processes in diesel is the most significant.

\section{Conclusion}

Thus, the analysis of modern directions of improving the process of managing fuel supply of powerful transport diesels makes possible to state that introduction of electric speed and load controllers during modernization is a fairly powerful means of increasing the economy at operation (modernizations 2 and 3 ).

The rate of increase in the operational fuel economy can be given in the technical materials only in a relative form, no numerical indicators of the increase in economy can exceed in percentage the values indicated in this paper. Namely, the locomotive section with the electric controller has demonstrated a decrease in fuel consumption at operation by $5-6 \%$.

Moreover, these indicators will most likely be lower because of the natural mechanical wear of the fuel supply system elements.

The qualification of the maintenance personnel and the technical condition of the diesel generator itself, as well as the degree of production load, influence significantly the final indicators of fuel consumption reduction.

The obtained results can be used in substantiating the application of various technical control and management systems.

\section{Conflict of interests.}

The authors declare that there is no conflict of interests regarding the publication of this paper.

\section{References}

[1] Schanes K, Jäger J, Drummond P (2018) Three Scenario Narratives for a Resource-Efficient and Low-Carbon Europe in 2050. Ecological Economics 155:70-79 . https://doi.org/10.1016/j.ecolecon.2018.02.009

[2] Hnatov A, Arhun S, Ulyanets O, Ponikarovska S (2018) Ultracapacitors Electrobus for Urban Transport. In: 2018 IEEE 38th International Conference on Electronics and Nanotechnology (ELNANO). Kyiv, Ukraine, pp 539-543, doi: 10.1109 / ELNANO.2018.8477449

[3] Petroff A (2017) These countries want to ban gas and diesel cars. In: CNNMoney. http://money.cnn.com/2017/09/11/autos/countriesbanning-diesel-gas-cars/index.html. Accessed 28 May 2018

[4] Migal V, Arhun Shch, Hnatov A, Dvadnenko V, Ponikarovska S (2019) Substantiating the Criteria For Assessing the Quality of Asynchronous Traction Electric Motors in Electric Vehicles and Hybrid Cars. Journal of the Korean Society for Precision Engineering 10:989-999, doi: 10.7736/KSPE.2019.36.10.989

[5] Pațins A, Hnatov A, Arhun S (2018) Safety of Pedestrian Crossings and Additional Lighting Using Green Energy. In: Transport Means 2018: Proceedings of 22nd International Scientific Conference. Kaunas University of Technology, Lietuva, Trakai, Kaunas, pp 527-531

[6] Hnatov A, Arhun S, Tarasov K, Hnatova A, Migal V, Patlins A (2019) Researching the Model of Electric Propulsion system for bus with the Matlab Simulink. In: 2019 IEEE 60th International Scientific Conference on Power and Electrical Engineering of Riga Technical University (RTUCON). Riga, Latvia, pp 1-6

[7] Asekar AK (2013) STOP-START system using microhybrid technology for increasing fuel efficiency. International Journal of Mechanical and Production Engineering 1:20-26

[8] Dvadnenko V, Arhun S, Bogajevskiy A, Ponikarovska S (2018) Improvement of economic and ecological characteristics of a car with a start-stop system. International Journal of Electric and Hybrid Vehicles 10:209-222 . https://doi.org/10.1504/IJEHV.2018.097377

[9] Agenjos E, Gabaldon A, Franco FG, Molina R, Valero S, Ortiz M, Gabaldón RJ (2009) Energy efficiency in 
railways: Energy storage and electric generation in diesel electric locomotives. Energy (Wh/kg) 10:1-10

[10] Babeł M, Szkoda M (2016) Diesel locomotive efficiency and reliability improvement as a result of power unit load control system modernisation. Ekspolatacja $i$ Niezawodnosc - Maintenance and Reliability 18:38-49. https://doi.org/10.17531/ein.2016.1.6

[11] Liudvinavičius L, Dailydka S (2017) The Aspects of Modernization of Diesel-Electric Locomotives and Platform for Transportation of Railway Switches in Lithuanian Railways

[12] (2017) Diesel locomotive upgrade deal signed. https://eng.lsm.lv/article/economy/transport/diesellocomotive-upgrade-deal-signed.a247775/. Accessed 28 May 2018

[13] Christiaens J (2018) Polish railway company PKP Cargo modernises 130 diesel locomotives. (Poland) | Eltis. In: Eltis. The urban mobility observatory. http://www.eltis.org/discover/news/polish-railwaycompany-pkp-cargo-modernises-130-diesel-locomotivespoland-0. Accessed 28 May 2018

[14] Liudvinavičius L, Jastremskas V (2017) Modernization of Diesel-electric Locomotive 2M62 and TEP-70 Locomotives with Respect to Electrical Subsystem. Procedia Engineering 187:272-280 https://doi.org/10.1016/j.proeng.2017.04.375

[15] Kalinčák D, Grenčík J (2016) Operational regimes of de locomotives and possibilities of fuel sav. TTS Technika Transportu Szynowego. Instytut Naukowo-Wydawniczy "TTS" Sp. z o.o 23:111-116

[16] Rasul MG, Patel A, Cole C, Sun Y, Spiryagin M, Godber T, Hames S (2013) Train Motive Power Technologies: $A$ Review on Existing and Emerging (Hybrid) Technologies. $1-11$

[17] (2001) Моделювання перехідних процесів тепловозного дизеля в експлуатаційному циклі 3 метою встановлення шляхів зниження витрат палива. ХарДАЗТ, Харків

[18] Коссов EE, Шапран EH, Фурман BB (2006). Совершенствование режимов работы силовых энергетических систем тепловозов. Восточноукр. нач. ун-т им. В.Даля, Луганск, рр 200-275

[19] Абрамчук ФИ, Левтеров АМ (2007) Опыт конвертации дизелей в газовые двигатели с искровым зажиганием. Автомобільный транспорт 21:1-4

[20] Woodward | Home. http://www.woodward.com/. Accessed 29 May 2018

[21] Start - HEINZMANN GmbH \& Co. KG. https://www.heinzmann.com/de/. Accessed 29 May 2018

[22] (2018) Woodward / Home. http://www.woodward.com/. Accessed 29 May 2018

[23] Кирьянов АН (2014) Эффективность работы тепловозов с электронной системой управления впрыском топлива. Локомотив 1:34-37

[24] Bogajevskiy A, Arhun S, Hnatov A, Dvadnenko V, Kunicina N, Patlins A (2019) Selection of Methods for Modernizing the Regulator of the Rotation Frequency of Locomotive Diesels. In: USB Proceedings of 2019 IEEE 60th International Scientific Conference on Power and Electrical Engineering of Riga Technical University (RTUCON2019), Latvia, Riga, 7-9 October, 2019. Piscataway: IEEE, 2019, pp. 045-1-045-6.

[25] Богаевский АБ (2008) Компьютерная модель мощного транспортного дизель-генератора с электронной системой управления. Открытые информационные и компьютерные интегральные технологии-Харьков: Наи аэрокосм ун-т «ХАИ 150-169

[26] Bogaevsky AB, Borisenko AN, Voitenko MS (2013) Evaluation of the possibility of reducing fuel consumption of a diesel generator of a shunting diesel locomotive by improving management. Internal combustion engines 1: 105-109 